Ankara Üniversitesi Türk İnklâp Tarihi Enstitüsü Atatürk Yolu Dergisi

S 35-36, Mayts-Kastm 2005, s. 333-343

\title{
Türk Basınına Göre; Ortodoks Türklerin Milli Mücadeledeki Tutumu
}

\section{Dr. İbrahim ERDAL *}

\begin{abstract}
ÖZET
Milli Mücadele döneminde Yunanistan kamuoyu oluşturmak için her türlü propagandayı uygulamıs, Anadolu'daki Hiristiyanları da Patrikhane vasitasılyla Milli Mücadele aleyhinde faaliyete çağırmıștır. Bu dönemde Ortodoks Türklerin sesi olan Papaz Eftim bu faaliyetlerin karşısında olmuş, Yunanlıların iddialarını verdiğ $i$ beyanatlarla bozmuştur. Bu makalede zararlı faaliyetler karşısında Ortodoks Türklerin Milli Mücadeleye olan tutumlart incelenmiştir.
\end{abstract}

Anahtar Kelimeler: Ortodoks Türkler, Milli Mücadele, Fener Patrikhanesi, Papa Eftim

According to Turkish Press; Attitude of Orthodoxs Turks in the National Struggle

ABSTRACT

During the Turkish National Struggle, in which Greece called for Anatolian Christian againts by means of Patriachate and used every means of propaganda methods in order to form an Greece public opinion. Pope Eftim who was representative ofthe Turkish Orthodoxs at that time opposed these activities and he violated the claimes of Greeks with his statements. In this article the attitudes of Turkish Orthodoxs opposing the detrimental activities were studied.

Key Words: Turkish Orthodoxs, The Turkish National Struggle, Fener Patriarchate, Pope Eftim

\section{GİRIŞ}

Milli Mücadele sırasında Yunanistan'ın en önemli propaganda malzemelerinden biriside Patrikhane ve Anadolu Hıristiyanlığı olmuştur.

•Pamukkale Üniversitesi Fen Edebiyat Fakültesi Tarih Bölümü. 
Gayrimüslimlerinin hukukunun muhafazası bahanesiyle Anadolu'nun işgali propagandası yapılmıştır. ${ }^{1}$ Burada Anadolu'daki bütün Hıristiyanların Rum olduğu iddiaları üzerine Ortodoks Türklerin itirazları yeni bir tartışmayı da gündeme getirmiștir. Atatürk'ün “Milli Mücadelede bize bir ordu kadar yardım etti" sözleriyle işaret edilen Papa Eftim ve Ortodoks Türkler ${ }^{2}$ hem faaliyetleri hem de Türklükleri açısından dönemin gazetelerinde yer bulmuştur. İzzet Ulvi Hakimiyet-i Milliye gazetesinde " Hıristiyan Türkler" başlıklı yazısında “... Karamanlılar Ortodoksluğu kabul ettikleri vakit kilisede Rumca ibadetten pek ziyade bikarak Bizans Imparatoruna şikayet etmişler, bunun üzerine kilisede bunlara Türkçe va'z edilmesine müsaade edilmiştir. ...Hulasa şünü söyleyeyim ki Anadolu tarihi ilk devirlerden beri Türk'tür...Sadece Türkçe konuşan Hiristiyanlar ise tamamen Türk'tür" demiştir. Köprülüzade Mehmet Fuat ise "Anadolu'da Hıristiyan Türkler" başlıklı yazısında " "... Türkçeden başka bir dil bilmeyen Anadolu Ortodokslarının eski lisanlarını unutmuş eski Anadolu Rumları olduğu nokta-i nazarını biz hiçbir suretle kabili müdafaa görmüyoruz... Ĕ̆ger dilleri unutulmuş olsaydl, Rum Ortodoksların da dillerini unutmaları gerekirdi.." diyerek propagandaya karşı durmuşlardır.

Batı Anadolu kıyıları, Karadeniz kıyıları ve Marmara bölgesinde yoğun olarak bulunan Hıristiyan Rumlara nazaran Anadolu'nun içlerinde yoğun diğer yerlerde ise az bir orana sahip olan Ortodoks Türklerin en önemli liderlerinden birisi Keskin Metropoliti Papa Eftim olmuş, 1884 yılında Yozgat Akdağmadeni'nde doğan Papa Eftim, 1918 yılında Keskin Metropolit vekili olmuştur. ${ }^{5}$

\section{Fener Rum Patrikhanesi'nin Faaliyetleri}

Anadolu'yu işgal ederek Bizans'ı tekrar kurma hayallerine kapılan Venizelos, askeri faaliyetlerinin yanında propaganda araçlarını da kullanmış, bu yolda en güvendiği işbirlikçisi de Fener Rum Patrikhânesi olmuştur. Yunanistan'ın desteğinde Rumlar tarafından kurulan cemiyetler, Patrikhâne'nin yönlendirmeleri ve maddî desteğiyle çalışmışlardır. Patrikhane kontrolünde faaliyet gösteren bu derneklerden bir kısmı; Amerika'ya, Yunanistan'a ve Adalara göç etmiş olan Rumların tekrar İstanbul'a dönmesini sağlayarak, Anadolu'da Rum nüfus ile ilgili iddiaları gerçekleştirmek istemiştir. Bir kısım cemiyetler de göçmen cemiyeti olarak

${ }^{1}$ Yavuz ERCAN, "Türk-Yunan İlișkilerinde Rum Patrikhânesi'nin Rolü”, Üçüncü Askeri Tarih Semineri Bildirileri, Tarih Boyunca Türk Yunan İlişkileri, Ankara 1986, s.204.

${ }^{2}$ Yavuz ERCAN, Fener ve Türk Ortodoks Patrikhanesi, Tarih Araştırmaları Dergisi,

C: V, S:8-9, Ankara 1967, s.416.

${ }^{3}$ Hâkimiyet-i Milliye, 18 Kasım 1921

${ }^{4}$ İkdam, 26 Aralik 1921

5 Teoman ERGENE, İstiklal Harbinde Türk Ortodoksları, İstanbul 1951, s.5-6; Mustafa EKİNCIKLLİ, Türk Ortodoksları, Ankara 1998; Yonca ANZERLIOĞLU, Karamanlı Ortodoks Türkler, Ankara 2003, s.221; ERCAN, Fener...., s.417. 
gösterildiğinden silahlı Rum çetelerini Anadolu'nun her yerine nakledebilmiş, bu cemiyetlerin seyahat belgesini alan çete üyeleri Karadeniz'de rahatça hareket edebilmişlerdir. Yunanistan kontrolünde hareket eden Patrikhane, Metropolitler aracılığıyla çetelere katılmak üzere gelen 18-20 yaş arası gençleri jimnastik ve izcilik faaliyetleri adı altında askeri eğitime tâbi tutmuştur. ${ }^{6}$

Patrikhânenin en önemli faaliyet sahasından birisi de Pontus meselesi çerçevesindeki faaliyetleri olmuştur. Yunanistan'ın bağımsızlığına kavuşması ve Filik-i Eterya örgütünün kurulmasıyla, Pontus'un bağımsızlığı "Megali Idea"nın hedeflerinden birisi olmuștur. 7 Patrikhâne'nin desteğiyle kurulan Milli Mücadele karşıtı cemiyetlere, Pontus cemiyetleri de katılmıştır. Pontus Cemiyeti; Trabzon, Ordu, Giresun, Samsun sahil Vilayetleri ile, Kastamonu, Gümüşhâne, Sivas ve Erzincan Vilayetlerinin bir kısmını içine alan yerleri, başkent Samsun olmak üzere Yunanistan'la birleştirmek üzere bağımsız bir Pontus cumhuriyetini kurmayı ve Birinci Dünya Savaşı'nın başladığı dönemlerde Bafra civarında ilk çetecilik faaliyetlerini başlatarak; Türk ordusunu meşgul edip düşmana geri hizmet vazifesi görmeyi, pusu kurmak ve bölgede Rum nüfusunu arttırarak Rum varlığını ve çoğunluk oluşturduğunu ispat etmeyi amaçlamıştır.

Karadeniz'deki Pontus faaliyetlerinin en önemli lideri Trabzon Metropoliti Hrisanthos, dolayısıyla Patrikhane olmuştur. Metropolitin kardeşleri Antaş ve Yorgi, Yunan ordusunda ve Pontus milis çeteleri içinde görev almış, Selanik ve Kafkaslarda Pontus çeteleri içinde komutanlık yapmışlardır. ${ }^{8}$ Yine Patrikhâneye bağlı olan Havza Papazı, Giresun Metropoliti Lavrentios ve Giresun belediye başkanının oğlu Konstantinidis Pontusçu faaliyetlerine Fener Patrikhânesinden aldıkları maddî manevî desteklerle devam etmişlerdir. Bu faaliyetler Birinci Dünya Savaşı başlarına kadar gizli gizli devam etmiş, savaşmamak için cepheden kaçan Rumlar, Rusların silah yardımıyla tekrar silahlandırılarak Pontusculuk faaliyetlerine dahil edilmişlerdir. Trabzon Metropoliti Hrisanthos, Rum çetelerinin daha düzenli hâle getirebilmek için "Rum İttihad-1 Milli Cemiyeti"ni kurdurmuş, Karadeniz vilayetlerinde şubeler açan bu cemiyet üyeleri Metropolite sadakatlerini bildirmişlerdir. ${ }^{9}$ Samsun Metropoliti Yermanos hem Müslümanlara hem de Rumlara karşı yapılan propagandadan ve yerel kuvvetlerden sorumlu iken, Trabzon Metropoliti Hrisanthos ise Fener Patrikhânesi'nin emir ve desteğiyle uluslararası görüşmelerde propaganda faaliyetinden sorumlu olmuştur. ${ }^{10}$ Faaliyetlerini Yunanistan doğrultusunda sürdüren Patrikhane Anadolu'daki Ortodokslarını Yunan ordusuna destek vermeleri için çalışmış, beklediği desteği göremeyince de kendileri için

\footnotetext{
${ }^{6}$ Tanin 31 Aralık 1922;

${ }^{7}$ Tanin 23 Temmuz 1923

${ }^{8}$ Hâkimiyet-i Milliye, 17 Mart 1922

${ }^{9}$ Hâkimiyet-i Milliye, 17 Mart 1922

${ }^{10}$ Hâkimiyet-i Milliye, 13 Mart 1922
} 
gelen Yunan ordusuna niçin yardım etmediklerini sorarak şikayette bulunmuştur. ${ }^{11}$

\section{Ortodoks Türklerin Milli Mücadeleye Karşı Tutumu}

Patrikhanenin baskılarını artırması ve metropolitlerin Yunan taraftarı faaliyetleri üzerine Safranbolu Rumları bir telgrafı gazetelerde yayınlamıştır. Safranbolulu Ortodoks Türkler yayınladıkları ve Fener Rum Patrikhanesi'yle olan görüş ayrılıklarını belirttikleri telgraflarında aynı mezhepten oldukları fakat kendilerine felaketten başka bir şey getirmeyen patrikhanenin faaliyetlerinden son derece rahatsız olduklarını bu sebeple Ortodoks Türklerin ayrı bir patriklik tesis ederek birlik oluşturmak istediğini bu fikre Anadolu'daki birçok Rum'un da katılacağını belirterek din birliği olmasının yanında Türk kimliklerine de vurgu yapan şu sözleri söylemişlerdir: ${ }^{12}$

“ Menşe', adet, ananat ve lisan itibariyle Türk olan bizler, şimdiye kadar "Pan Elenizm" amalinin husulüne has mesai eden İstanbul Rum Patrikliğinin taht-ı tazyik ve tesirinde kaldık milliyetimizi izhar edemedik. Filhakika sahaif-i tarih tetkik edilecek olursa ezmine-i mütekaddimede Ortodoks mezhebini kabul etmiş Türk olduklarında şüphe kalmayan ve fakat tazyikat-ı maruzadan dolayı Rum namı altında yaşayan kardeşlerimizden mezkur patrikliğin teşvikat ve telkinatına tabi olan, ara sıra yanlış yolara gidenler de oldu. Buna rağmen bizler yine Türklerden, Türkiye hükümetinden daima adil ve şefkatle muamele gördük. Bundan sonra da Pan Elenizm amal ve cereyanlarina katiyen tabi olmayarak aslen kardeşlerimiz olan Türklerle mes'ud ve müreffeh bir halde yaşamak arzusundayız. Anadolu'da bulunan ırkdaşlarımızın amal-i perverde ettiklerine şüphemiz yoktur..." bu telgraf İstanbul basınında da yankı bulmuş, "Anadolu Rumları ve İstanbul Patrikliği" manşetinde ayrılık isteği belirtilmiştir. ${ }^{13}$

Telgrafta bir daha Fener Rum Patrikhanesinin zararlı faaliyetlerine katılmayacaklarını söyleyen ve Safranbolu'da yaşayan 2.749 Ortodoks Türklerin adına Kırımlığlu Hristo, Bazı kariyesi Muhtarı Yorgi, Kilise mahallesi muhtarı Yermanos, Ppaz Dimitri, Kilise Heyetinden Dimitri Kemikçioğlu, Hanyar mahallesi muhtarı Vasil, Kırkakan mahallesi muhtarı Ekmekçioğlu Anastas, Dolambaş mahallesi muhtarı Vasil ve eşraftan Çerkiroğlu İstavri, Kıratoğlu Hacı Yovan, Ekmekçioğlu Yovan, Şerbetçioğlu Mihail imza atmıştır. Ayrıca Isparta'da yaşayan Ortodoks Türkler çektikleri telgrafta papazlarının bile Türk olan yerli ahaliden yetiş̧tirilmiş olduğunu, İstanbul ile hiçbir alakalarının olmadığını bildirmiştir. ${ }^{14}$ Yine aynı gazetede yayınlanan telgraflarda Havza piskoposu; "Hükümet, matbuamız ve İslam

${ }^{11}$ Hâkimiyet-i Milliye, 18 Nisan 1921

${ }^{12}$ Hâkimiyet-i Milliye, 1 Mayıs 1921; Zekeriya TÜRKMEN, "İstiklal Harbi Yıllarında Türk Ortodokslarının Fener Rum Patrikhanesine karşı Yürüttükleri Propaganda Faaliyeti”, Askeri Tarih Bülteni, Subat 1999, Yıl:24, Sayı: 46, s.72.

${ }_{14}^{13}$ Vakit, 13 Mayis 1921

${ }^{14}$ Vakit, 3 Mayis 1921 
vatandaşlarımız nazarında sıkıntıya sebep olan İstanbul Patrikhanesinin hilaf-ı salahiyeti siyasi ve idari şekillere kadar çevirdiği nüfuzu ruhaniyesi'nin üzerimizden atıyoruz." demiştir. Gümüşhacıköy reisi ruhaniyesi de telgrafnamesinde Türk kimliğine vurgu da bulunarak "Bugün Anadolu'da asırlardan beri yaşayan Rumlar aslen Selçukilerden olup, Hıristiyanlığı kabul etmiş has Türklerdir." demiştir. Kayseri ve Tosya'dan gönderilen telgraflarda da ayrı bir patrikhanenin kurulması gereği belirtilmiştir.

Bunun yanında Konya Türk Ortodoksları adına Papa Nikola Avrupa ve Amerika Dışişleri bakanlarına çektiği ve Anadolu'da yaşamak istediklerini belirten telgrafında; ${ }^{15}$ "Biz aşă̆ı Ortodokslarl, yedi asırdan beri ecdadımız Türk tabiyetinde huzur ve rahat içindeyiz. Hiçbir müdahale olmaksızın kardes ve vatandas olarak yaşamaktayız." diyen Nikola, Yunanistan ve İstanbul Fener Patrikhanesinin sözde Anadolu Hıristiyanlarının zulüm gördüğüne dair olan iddialarının asılsız olduğunu belirterek yine aynı telgrafta "Bunlar Türklerle bizim çok eski olan dostluğumuzu soğutmak içindir. Biz bu memleketten ayrılmak arzu emelinde değiliz. Ecdadımız burada yaşadı, evladımız da Türklerle beraber yaşayacaktır." demiştir. Vakit gazetesi Ortodoks Türklerin ayrı patrikhane isteğine dayanan bu şikayetlerini bir Yunan gazetesi olan Atnos'a dayanarak vermiştir. Atnos gazetesinin haberine göre merkezi Kayseri olacak olan patriklik şimdilik Ankara'da kurulmuş, vekaleten de sabık Eskişehir metropoliti Papa Yani getirilmiş, Patrik kaymakamı olan Papa Yani'nin ismi de Yovani Efendi olmuştur. ${ }^{16}$

Fener Patrikhanesinin Anadolu Hıristiyanları'nı Rum olarak bütün dünyaya tanıtmasını ve bu konu üzerinden propaganda yapmasını yani Anadolu'nun çeşitli bölgelerinin sözde Rum Hıristiyanlarını kurtarmak amacıyla işgali propagandasına engel olmak amacıyla yine keskin Metropoliti olan Papa Eftim gazetelerde de yayınlanan bir bildiri yayınlamıș, bu bildiride ${ }^{17}$; "Anadolu'da bizim örf ve adetlerimiz hilafinda bir kanun yoktur. Kanunlarımız örf ve adetlerimize göre tanzim edildiği cihetle bize yabancı değildir. Fener Patrikhanesi Anadolu Hıristiyanlarının selametinin nerede olduğunu düşünerek, Avrupa siyasilerini propagandalarla yanlış yola sevk ettiklerini bütün delilleriyle ve açıklıkla gösterebiliriz." demiştir. Türk ordularının kazandığı başarılarına siyasi başarılarını da eklenmesi üzerine faaliyetlerini artıran Fener Patrikhanesi hakkında sürekli uyarılarda bulunan Papa Eftim, Avrupa'nın müdahalelerinin de olması sebebiyle Hakimiyet-i Milliye gazetesine bir beyanatta bulunmuş, bu beyanatında ${ }^{18}$; “ Simdiye kadar Osmanlı ișlerine müdahale vesilesi olmuş olan bu Hıristiyanlık meselesini Türkiye Büyük Millet Meclisi halk hükümeti göğsünden budamalıdır. Çünkü, burada Avrupa'nın himayesine muhtaç bir

\footnotetext{
${ }^{15}$ Hâkimiyet-i Milliye, 16 Haziran 1921.

${ }^{16}$ Vakit, 7 Haziran 1921

${ }^{17}$ Hâkimiyet-i Milliye, 7 Kasım 1921.

${ }^{18}$ Hâkimiyet-i Milliye, 9 Kasim 1921.
} 
ırk değil, onlardan gölge etmemelerini isteyen bir Huristiyan- Türk kardeş ırk vardır." demiştir. Papa Eftim Efendi, beyanatında Türklerin batıdan doğuya kadar birçok kültürle medeniyetle ticari ve siyasi temaslarda bulunduğunu ancak kesinlikle dilini unutmadığını belirtmiş, Budist, Şaman, İslam, Musevi, Hıristiyan olan Türklerin bu dinleri kabul etmelerine karşın dillerini unutmadıklarını söyleyerek, Türk'ün esas karakteri budur demiştir. Buna rağmen dillerini unutmadıklarını belirten Papa Eftim Efendi, Fener Rum Patrikhanesi'nin bu özellikleri üzerine uyguladığı politikalardan bahisle; "1826 tarihine kadar Fener Patrikhanesinin aile ocaklarında, kiliselerde gizli gizli yaşattığı Türk düşmanllğı o tarihten sonra hariçte, bir siyasi destek bularak isyan şeklinde meydan almıştı ki, İşte Anadolu Hiristiyanlarına bundan sonra Yunan Metropolitler musallat olmuştur. Bir asırdan beri iki nesil değiştiği ve bunlar Osmanlı Hükümeti'nin geçirdiği bu kadar inhilallerden istifade ile Anadolu Türk Hıristiyanlarını ruhen, cismen tahakküm ve nüfuzlarl altına aldıklarl halde acaba Anadolu Hıristiyanlarının milli vicdanını, milli dehasını, milli dinini bozabilmişler midir?" demiştir. Papa Eftim bütün bunlara dayanarak Patrikhanenin yüzyıldır uyguladığı planların tutmadığını, buna rağmen Müslüman Türklerin kendileriyle ilgilenmediğini TBMM hükümetinin dış devletlerle olan görüşmelerde bu hususu iyi bilmesini belirtmiştir.

Fener Rum Patrikhanesinin faaliyetleri karşısında Milli Mücadele yanlısı bir tavır sergileyen Ortodoks Türkler ve Ruhani liderleri Papa Eftim Efendi, TBMM Hükümetini patrikhanenin faaliyetleri hakkında uyarmıștır. Ayrıca Anadolu'daki diğer Ortodokslara bir bildiri yayınlayarak ${ }^{19}$, Anadolu Hıristiyanlarını dışardan gelecek propagandalara inanmamaları, Fener Rum Patrikhanesinin bölücü faaliyetlerine katılmamaları ve Milli Mücadele safında yer almalarını tavsiye etmiş, Eftim Efendi, Ortodoks Türklere Müslüman Türklerle her şeylerinin müşterek olduğunu belirtmiştir. Papa Eftim Efendi, Anadolu'da bir ekalliyet olmadığını yalnız Hıristiyan ve Müslüman Türklerin olduğunu belirterek kurulan hükümetin kendi hükümetleri olduğunu söylemiştir. Papa Eftim Efendi, Fener Rum Patrikhanesinin faaliyetleri karşısında yayınladığı bu beyanatın bütün Ortodoks Türk kiliselerinde okunmasını da istemiştir.

Papa Eftim Efendi'nin bu beyanatı sonrasında Çorum Ortodoks Kilisesi Metropoliti Papa Nikola ve Çorum Ortodoks eşrafından olan Gülistanoğlu Hrisantos TBMM hükümeti Adliye Vekaletine bir rapor göndermiştir. ${ }^{20} \mathrm{Bu}$ raporda Çorum Metropoliti olan Papa Nikola, Keskin Metropoliti Papa Eftim Efendi'nin beyanatına katıldıklarını belirttikten sonra asırlardan beri geniş bir din özgürlüğü içinde yaşadıklarını, Anadolu'da Rum, Elen veya Grek adıyla bir millet olmadığını, Turan ırkından Türk milleti olup İseviliği kabul eden Türklerin var olduğunu belirtmiştir. Bu raporda dikkat çeken en önemli

\footnotetext{
${ }^{19}$ Hâkimiyet-i Milliye, 30 Kasım 1921; İkdam, 2 Aralık 1921

${ }^{20}$ Hâkimiyet-i Milliye, 22 Aralık 1921; İkdam, 30 Aralık 1921
} 
husus ise Papa Nikola'nın Türk Ortodokslarının Fener Patrikhanesinden ayrı bir patriklik teşkil etmek arzusunda olduklarına dair sözleridir.

Papa Eftim Efendi, Amerikalı gazeteci Mrs. Prayz'a verdiği mülakatta ${ }^{21}$ kendilerinin Türk asıllı olduklarını sadece dinlerinin farklı olduğunu, Müslüman Türk kardeşlerinin verdikleri geniş imtiyazlar altında asırlardır rahat ve huzur içinde yaşadıklarını belirtmiştir. Papa Eftim Efendi yine aynı mülakatta Fener Patrikhanesinin asıl vazifesinden uzaklaşarak siyasi davrandığını, entrikalara alet olduğunu bu sebeple ayrılmak istediklerini belirtmiştir. Papa Eftim Efendi ayrılık kararını " İstanbul'dakiler kendilerini Yunan ilan ediyorlar, biz de bütün cihana Türk olduğumuzu bağırıyoruz. 600 senedir mevcudiyetimizi muhafaza eden kimdi? Türk hükümeti değil mi? Patrikhaneyi takbih etmekliğimiz yalnız sözle değildir. Aynı zamanda fiilen de intihaba iştirak etmemek suretiyle kendilerinden ayrlmak arzusunu gösterdik. Kendi ırkımızı bırakarak yabancı bir ırkın aleti olmak istemiyoruz." sözleriyle ifade etmiştir.

\section{Ortodoks Türk Patrikhanesinin Kuruluşu}

Patrikhâne'nin desteğiyle faaliyetlerini arttıran Rum çetelerine karşı halk milis kuvvetler oluşturarak karşı koymaya başlamıştır. Ortodoks Rumların faaliyetleri karşısında yine Ortodoks tebaa olan, örf ve adet itibariyle Müslüman Türklere daha yakın bir hayat süren Hıristiyan Türkler ise Kuvay-1 Milliye lehinde çalışmışlardır. Papaz Eftim'in önderliğindeki Çorum, Safranbolu, Isparta, Kayseri gibi merkezlerdeki Ortodoks Türkler, Hükûmete çektikleri telgraflar ve görüşmelerde Türkçe'den başka bir dil bilmediklerini ve Türk olduklarını ifade etmişler, bir Türk Ortodoks Patrikhânesi'nin kurulmasının gereğine işaret etmişlerdir. Papa Eftim Efendi'nin de Refik Şevket Bey'e yaptı̆̆ vurgulanmış, bu isteğe bütün Ortodoks Türkler de katılmıştır. ${ }^{22}$

Bütün bu birliktelik üzerine de Papa Eftim Efendi 6 Ocak 1922 tarihinde Anadolu'daki bütün Ortodoks Türklere bir beyanname yayınlayarak; Fener Patrikhanesinin emirlerine kesinlikle uyulmamasını, bazı müfsitlerin faaliyetlerine kanılmamasını hatırlatarak birlik çağrısında bulunmuştur. ${ }^{23}$ bu talebe de hem Adliye Vekili Reşit Şevket Bey, hem de Hükûmet temsilcisi Bekir Sami Bey olumlu bakmıştır. ${ }^{24}$ Fener Rum Patrikhânesi Ortodoks Türklerin bu karşı faaliyeti üzerine olağanüstü toplanarak bu durumu kabul etmediğini bildirmiş, ${ }^{25}$ ancak Adliye Vekaleti Türk Ortodoks Patrikhânesi'nin kurulması hakkındaki kanun teklifini TBMM'ye sunmuştur. ${ }^{26}$

\footnotetext{
${ }^{21}$ Hâkimiyet-i Milliye, 28Aralık 1921

${ }^{22}$ Vakit, 30 Aralık 1921; Hâkimiyet-i Milliye, 27 Aralık 1921; 28 Aralık 1921.

${ }^{23}$ Hâkimiyet-i Milliye, 6 Ocak 1922

${ }_{24}^{4}$ İkdam, 31 Aralık 1921; Hâkimiyet-i Milliye, 10 Ocak 1921,

${ }^{25}$ Hâkimiyet-i Milliye, 15 Mayıs 1921 .

${ }^{26}$ Íkdam, 3 Mayis 1921
} 


\section{Sonuç}

Lozan Görüşmeleri sırasında da gündeme gelen Ortodoks Türklerin Patrikhane kurması konusu olmuştur. Hüseyin Rauf Bey İsmet Paşa'ya gönderdiği telgrafta Kayseri'de Türk Ortodoks Kilisesi namında bir kilise kurulması için metropolitlerden oluşan bir Sinod'un oluşturulduğu Kayseri, Konya ve Ankara'ya Metropolitlerin atandığı bildirilmiştir. ${ }^{27}$ Ortodoks Türkler, Fener Rum Patrikhânesinin zararlı faaliyetleri karşısında 1922 yılında bağımsız Türk Ortodoks Patrikhânesini kurarak, Fener Rum Patrikhânesinin nüfuzunu kırmaya çalışmışlardır. Milli mücadele lehinde çalışan Anadolu'nun Ortodoks Türkleri, bütün vekalet ve yetkileri Papa Eftim'e verdiklerini ve onu desteklediklerini bildirmişlerdir. ${ }^{28}$ Papa Eftim'de Ankara'ya çağırdığı yabancı gazetecilere Fener Patrikhânesi'nin yaptığ asılsız propagandaların iç yüzünü anlatmış, Anadolu'da yaşanan hadiselerden Hıristiyanların da zarar gördüğünü buna sebep olanın da Fener Patrikhânesi olduğunu ifade etmiştir. Milli Mücadeleye katkılarına rağmen Lozan görüşmelerinde Ortodoks Türkler, diğer Rum tebaa ile birlikte mübadeleye tâbi tutulmuştur. Ortodoks Türklerin başvuruları sonucu 3 Ağustos 1924 tarihli kararla sadece Papa Eftim ve ailesi mübadele harici tutulmuştur. ${ }^{29}$ Bugün de, Ortodoks Türk Patrikhanesi Milli Mücadele döneminde $d_{1}$ ş propagandalar karşısında aldığ 1 tutumun aynısını sergilemektedir.

\section{KAYNAKLAR}

\section{Arşiv Belgeleri}

Başbakanlık Cumhuriyet Arşivi: 30.18.1.1./10.37.1

\section{Gazeteler}

Hâkimiyet-i Milliye, 18 Kasım 1921, 17 Mart 1922, 13 Mart 1922, 18 Nisan 1921, 1 Mayıs 1921, 16 Haziran 1921, 7 Kasım 1921, 9 Kasım 1921, 30 Kasım 1921, 22 Aralık 1921, 28Aralık 1921, 27 Aralık 1921, 6Ocak 1922, 10 Ocak 1921, 15 Mayis 1921, 13 Ocak 1922

İkdam, 2 Aralık 1921, 26 Aralık 1921, 30 Aralık 1921, 31 Aralık 1921, 3 Mayıs 1921

Tanin 31 Aralık 1922, 23 Temmuz 1923

Vakit, 3 Mayıs 1921, 13 Mayıs 1921, 7 Haziran 1921, 30 Aralık 1921

\section{Kitaplar ve Makaleler}

ANZERLIOĞLU, Yonca, Karamanlı Ortodoks Türkler, Ankara 2003.

${ }^{27}$ Bilal ȘIMȘíR, Lozan Telgrafları (1922-1923) I, Türk Tarih Kurumu yayını, Ankara 1990, s.296-297.

${ }^{28}$ Hâkimiyet-i Milliye, 13 Ocak 1922

${ }^{29}$ Başbakanlık Cumhuriyet Arşivi: 30.18.1.1./10.37.1 
TÜRK BASININA GÖRE; ORTODOKS TÜRKLERINN MILLI MÜCADELEKİ YERİ 341

EKİNCIKLİ, Mustafa, Türk Ortodoksları, Ankara 1998

ERCAN, Yavuz, Fener ve Türk Ortodoks Patrikhanesi, Tarih Araştırmaları Dergisi, C:V, S:8-9, Ankara 1967.

ERCAN, Yavuz, Türk-Yunan İlişkilerinde Rum Patrikhânesi'nin Rolü, Üçüncü Askeri Tarih Semineri Bildirileri, Tarih Boyunca Türk Yunan İlişkileri, Ankara 1986, s.204.

ERGENE, Teoman, İstiklal Harbinde Türk Ortodoksları, İstanbul 1951.

ŞİMŞİR, Bilal, Lozan Telgrafları (1922-1923) I, Türk Tarih Kurumu yayını, Ankara 1990.

TÜRKMEN, Zekeriya, "İstiklal Harbi Yıllarında Türk Ortodokslarının Fener Rum Patrikhanesine karşı Yürüttükleri Propaganda Faaliyeti”, Askeri Tarih Bülteni, Şubat 1999, Yıl:24, Sayı: 46, s.72. 

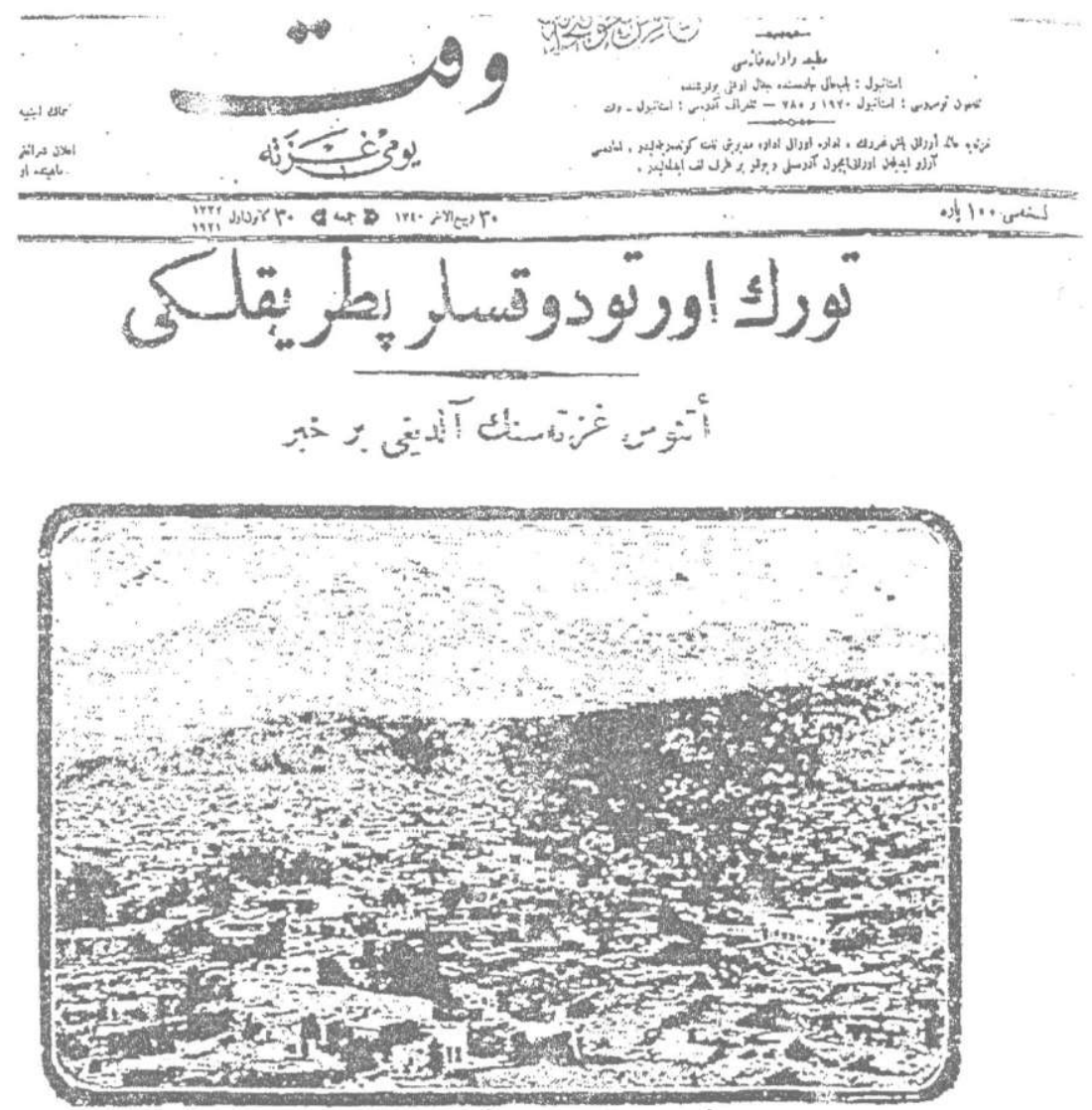

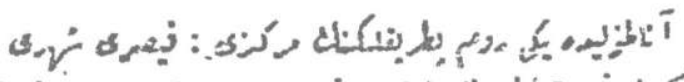

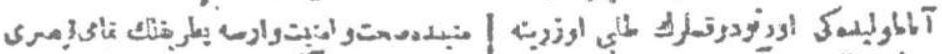

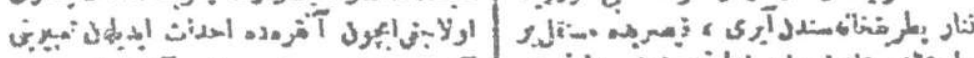

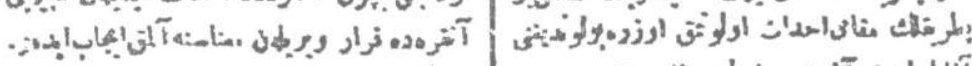

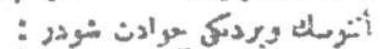

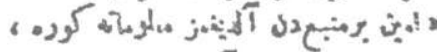

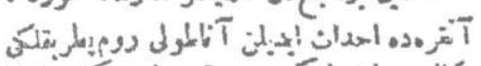

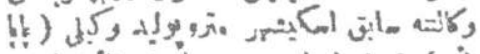

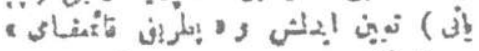

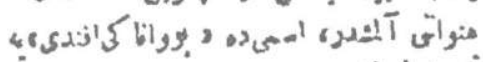

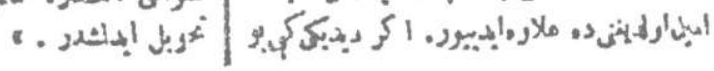
Ek: Yunanistan'da yayınlanan Atnos gazetesinde Ortodoks Türk Patrikhanesi ile ilgili Haber,
Vakit 7 Haziran 1921 


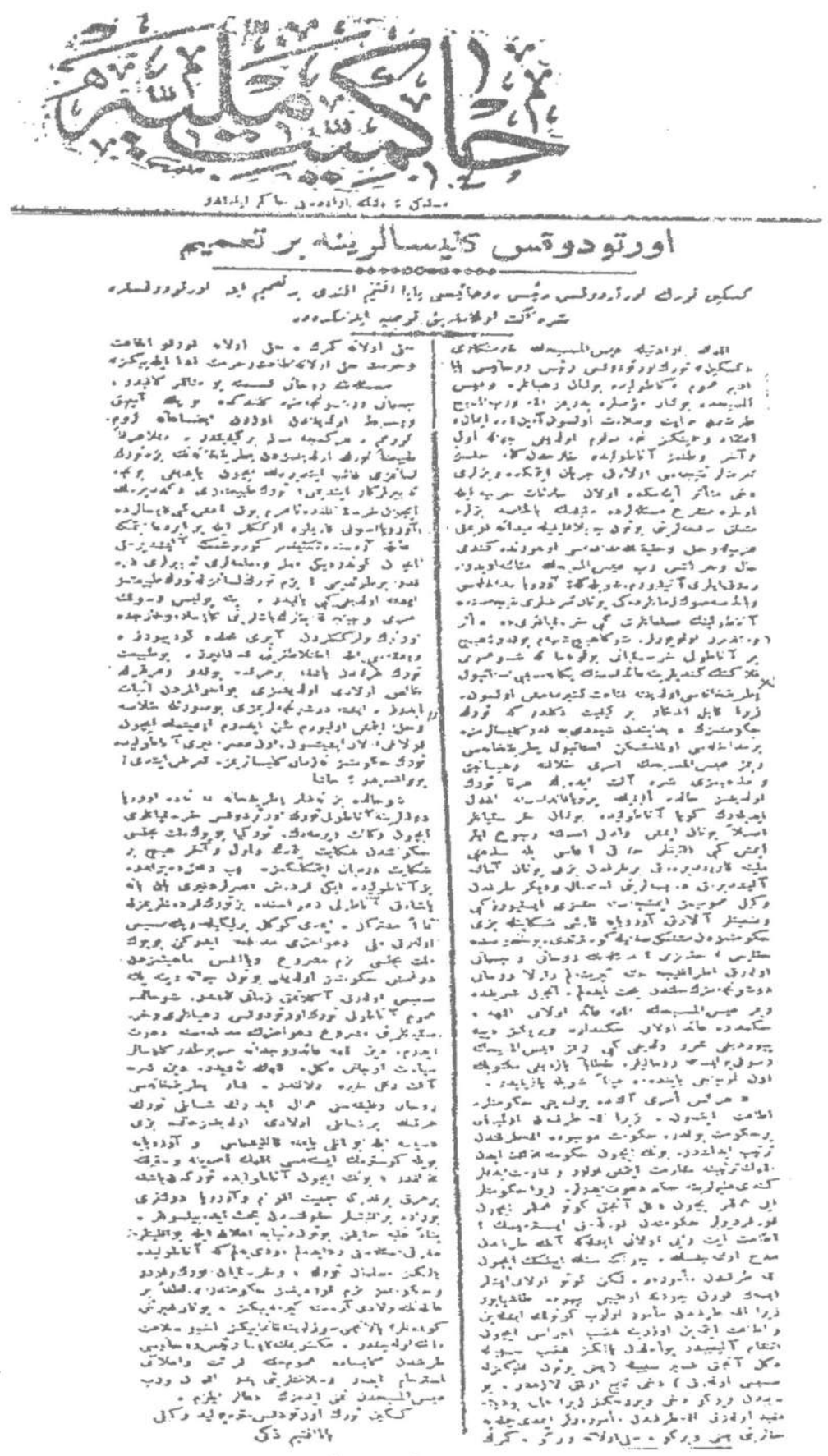

Papa Eftim Efendi'nin Ortodoks Türklere Çă̆rısı, Hakimiyet-i Milliye, 1 Aralık 1921 